\title{
Characterization of Botrytis cinerea From Commercial Cut Flower Roses
}

\author{
M. Muñoz, J. E. Faust, and G. Schnabel ${ }^{\dagger}$ \\ Department of Plant and Environmental Sciences, Clemson University, Clemson, SC 29634
}

\begin{abstract}
Botrytis cinerea Pers. infects cut flower roses (Rosa $\times$ hybrida L.) during greenhouse production and gray mold symptoms are often expressed in the postharvest environment, resulting in significant economic losses. Disease management is based on cultural practices and preventative chemical treatments; however, gray mold outbreaks continue to occur. Rose tissues from six commercial shipments from two greenhouses in Colombia were evaluated to determine the Botrytis species composition as well as identify other pathogens present, gray mold incidence and severity, and fungicide resistance profiles. Botrytis isolates (49 total) were grouped into six morphological phenotypes, and all were identified to be $B$. cinerea sensu stricto. Disease incidence was higher in the petals than in the stem, stamen, ovary, sepal, or leaf tissues. Other fungi were isolated infrequently and included

Alternaria alternata, Cladosporium cladosporioides, Epicoccum nigrum, Penicillium citrinum, Aspergillus brasiliensis, and Diplodia sp. Fungicide resistance profiles were determined using previously established discriminatory doses. Isolates resistant to thiophanatemethyl, iprodione, boscalid, and cyprodinil were found frequently in all shipments and in both greenhouses. The frequency of resistance to penthiopyrad, fenhexamid, fluopyram, isofetamid, and fludioxonil varied between shipments and greenhouses. No resistance to pydiflumetofen was observed at the discriminatory doses tested. Isolates with resistance to multiple chemical classes were commonly found. These results indicate that fungicide resistance management practices may improve preharvest and postharvest gray mold control of cut flower roses.
\end{abstract}

Gray mold is a destructive fungal disease caused primarily by $\mathrm{Bo}$ trytis cinerea Pers., a ubiquitous fungal pathogen affecting more than 235 plant species around the world (Andrew et al. 2012), including roses (Rosa $\times$ hybrida $\mathrm{L}$.). The disease reduces cut flower rose yield and postharvest quality (Vrind 2005). B. cinerea is disseminated mainly by airborne conidia, which are produced on conidiophores (Holz et al. 2007). The pathogen can affect different plant tissues, including leaves, stems, and flowers. However, the most severe economic damage occurs when the pathogen infects the flower petals (Elad 1988). Diseased flowers can be imperceptible at harvest because infections may remain latent until environmental conditions are favorable for tissue colonization. The favorable conditions for B. cinera growth include high relative humidity $(>94 \%)$ and temperatures ranging from 15 to $25^{\circ} \mathrm{C}$ (Williamson et al. 2007). The initial symptoms appear as small lesions that develop into necrotic tissue, leading to the collapse of the petals and flower head (Elad 1988).

B. cinerea has been described as a morphologically and genetically variable species (Elad et al. 2007). Research conducted in several fruit crops has shown that gray mold disease caused by $B$. cinerea can be the result of a species complex with different genetic groups that may vary with the season, tissue, and host preference (Fournier and Giraud 2008; Giraud et al. 1999). Staats et al. (2005) described a comprehensive DNA sequence-based methodology to more accurately distinguish between Botrytis species using the

${ }^{\dagger}$ Corresponding author: G. Schnabel; schnabe@clemson.edu

Funding: This research was funded by the American Floral Endowment. This material is based on work supported by the U.S. Department of Agriculture National Institute of Food and Agriculture under project number SC1700501 (Technical Contribution of the Clemson University Experiment Station).

*The $\boldsymbol{e}$-Xtra logo stands for "electronic extra" and indicates that two supplementary tables are published online.

The author(s) declare no conflict of interest

Accepted for publication 21 January 2019.

(c) 2019 The American Phytopathological Society nucleotide sequences of glyceraldehyde 3-phosphate dehydrogenase $(G 3 P D H)$, heat-shock protein 60 (HS60), and DNA-dependent RNA polymerase subunit II (RPB2) genes. These genes used to form the phylogenetic trees are essential for and often unique to the pathogen because they code for enzymes involved in different cellular processes (Staats et al. 2005). Based on these sequences, and considering the presence or absence of transposable elements (Walker 2016), and microsatellite amplifications (Váczy et al. 2008), B. pseudocinerea was identified as a pathogen causing gray mold in different fruit crops, including grapes, blackberries, and strawberries (Plesken et al. 2015). More cryptic species, including B. caroliniana and $B$. fragariae, were identified to cause gray mold of strawberry (Dowling and Schnabel 2017; Li et al. 2012; Rupp et al. 2017). Different Botrytis species have been identified on ornamental plants, including B. narcissicola on narcissus; $B$. calthae as a host-specific species on Caltha, occurring simultaneously with $B$. pseudocinerea and $B$. cinerea; $B$. pelargonium on geranium; and B. convoluta on iris (Walker 2016). Botrytis species have been previously identified in cut roses using polymerase reaction (PCR)-restriction fragment length polymorphism (RFLP) and restriction enzymes to evaluate whether B. pseudocinerea was part of the disease complex causing gray mold (Gómez-Rodríguez 2013). Gómez-Rodríguez (2013) determined that only $B$. cinerea sensu stricto was present in the roses; however, this assessment was not based on key genes used for phylogenetic analysis, including $G 3 P D H, H S 60$, and $R P B 2$.

One of the principal strategies for gray mold management relies on weekly preventative fungicide applications including multisite and site-specific fungicides (Hahn et al. 2014); however, the genetic plasticity and high adaptability of $B$. cinerea have resulted in resistance development to various single-site fungicides. Isolates may possess resistance to single or multiple fungicide classes, termed chemical class resistance (CCR) (Elad et al. 1992; Grabke et al. 2012; Jiang et al. 2009). B. cinerea isolates with multiple CCR have been observed on different crops, including cucumber, grapes, and strawberries (Amiri et al. 2013; Elad et al. 1992; Fernández-Ortuño et al. 2014; Leroch et al. 2013). Resistance monitoring has been implemented to improve resistance management programs in order to preserve the efficacy of fungicides and improve disease control (Fernández-Ortuño et al. 2014; Hu et al. 2016). Whether Botrytis from Colombian roses is resistant to fungicides is unknown. The objectives of this study were to evaluate commercial shipments of cut 
flower roses to determine (i) the Botrytis species and other pathogens present, (ii) the incidence and severity of gray mold on different cut flower tissues, and (iii) the occurrence of fungicide resistance in isolates from cut rose shipments.

\section{Materials and Methods}

Plant material and Botrytis isolates. Six shipments of commercial cut roses (Rosa $\times$ hybrida L.) from the Botrytis-susceptible cultivar Orange Crush were received between December 2016 and March 2017 from two greenhouses (A and B) located at Sabana Cundiboyacene in Colombia, South America $\left(4^{\circ} 59^{\prime} 16.9^{\prime \prime} \mathrm{N}, 73^{\circ} 59^{\prime} 36^{\prime \prime}\right.$ $\mathrm{W} ; 2,650$ m.a.s.l). The roses were produced within the same facility. Nearby facilities included potato production and other rose production farms. The greenhouses were $400 \mathrm{~m}$ apart and $150 \times 60 \mathrm{~m}$ in dimension. The roofs and sides were plastic and allowed for air ventilation during the day and night. The rose plants were produced in hydroponic systems using rice husks as a substrate. The production systems in both greenhouses were virtually identical; however, the setup of the two greenhouse floors varied slightly. Greenhouse A did not have any ground cover, whereas greenhouse B had brick paths installed in areas of highest human activity. Gray mold disease was managed in both greenhouses with cultural practices, including removal of diseased or detached plant tissues on a regular basis and forced air circulation using fans. Fungicides used during the experiment for gray mold management were the protectants captan, ziram, mancozeb, and chlorothalonil as well as the site-specific fungicides belonging to Fungicide Resistance Action Committee (FRAC) codes $3,7,9,11$, and 29. According to the producer, representatives of FRAC codes 1 and 2 were used in previous years. Also, FRAC 12 fungicides were used recently. Protectant fungicides were applied and rotated on a weekly interval for gray mold management in both greenhouses. In addition, weekly rotations of site-specific fungicides were based on FRAC codes. Not only the same FRAC code but also the same fungicides were applied in both greenhouses.

The roses were harvested and packaged as commercial bouquets of 25 roses per greenhouse. Each bouquet was wrapped in a clear plastic film covering the side of the flowers, and the bouquets were shipped in cardboard boxes. The shipments were received within 1 week at Clemson University and immediately processed. From each shipment and greenhouse, a set of five roses was arbitrarily selected from each bouquet. Each flowering stem was divided into five different groups of tissues: petals (three outer petals, three mid petals positioned inside the outer petals, and three inner petals in direct contact with the stamens and ovary), leaves, sepals, stamens and ovaries, and the entire stem cut into $15-\mathrm{cm}$ sections. The tissues were surface sterilized for $1 \mathrm{~min}$ in a sodium hypochlorite solution $(0.525 \%)$, immersed for $1 \mathrm{~min}$ in sterile deionized water and air dried for $5 \mathrm{~min}$ to kill any spores that may have come in contact with the flowers during the transportation process. Then each tissue type from each rose was individually placed in 15-cm-diameter Petri dishes with moist filter paper covered with a lid and placed in a clear (3.78-liter) sealable bag. Bags were kept at $-20^{\circ} \mathrm{C}$ for $24 \mathrm{~h}$ and then incubated for 7 days at $22^{\circ} \mathrm{C}$ and $100 \%$ relative humidity with intervals of $12 \mathrm{~h}$ of light and $12 \mathrm{~h}$ of darkness. Gray mold incidence was determined as the percentage of samples that developed disease symptoms or signs. Gray mold severity was determined based on the percentage of symptomatic area per tissue type. The affected area was calculated based on the total area of the tissue showing symptoms or signs of the disease. The incidence of other culturable fungi occurring in the rose tissues was also recorded, and the identity of the pathogens was determined as described below.

Morphological and phenotypic characterization of fungal isolates. Forty-nine Botrytis isolates and 20 non-Botrytis fungal isolates were collected from symptomatic rose tissue from the six shipments. Each isolate came from a different tissue sample. For single-spore isolation, spores were spread onto water agar and Petri dishes $\left(9-\mathrm{cm}\right.$ diameter) and were placed in the dark at $22^{\circ} \mathrm{C}$ for $16 \mathrm{~h}$ to promote conidia germination. Individual germinated conidia were removed from the water agar under a dissection microscope using a sterile scalpel and then placed onto potato dextrose agar (PDA) medium (Difco Laboratories). Morphological characters of single spore colonies were assessed after 10 days at $22^{\circ} \mathrm{C}$ with intervals of $12 \mathrm{~h}$ of fluorescent light and $12 \mathrm{~h}$ of darkness. Isolates were stored in the form of dried mycelium on filter paper. To verify the pathogenicity of the non-Botrytis isolates, healthy rose petals were surface sterilized with sodium hypochlorite solution $(0.525 \%)$ as was described previously for Botrytis isolation. Then six individual petals were inoculated with $10 \mu \mathrm{l}$ of spore suspensions $\left(1 \times 10^{6}\right.$ spores $\left./ \mathrm{mL}\right)$ obtained from 10-day-old cultures. Inoculated petals were individually placed onto moist filter paper in 9-cm-diameter Petri dishes and placed in clear (0.95-liter) sealable bags. Bags were incubated at $22^{\circ} \mathrm{C}$ and $100 \%$ relative humidity for 7 days. Symptom and sign development was evaluated. The fungi were reisolated from symptomatic tissue and morphologically compared with the fungus used for the initial inoculation.

DNA extraction, PCR amplification, and sequencing. DNA sequencing was performed on single-spore Botrytis isolates from each morphological type and resistance profile, as well as on non-Botrytis isolates. The isolates were cultured on PDA as described above for 7 days, except that cellophane paper (Research Products International Corp.) was used to cover the medium surface. Approximately 10 to $20 \mathrm{mg}$ of aerial mycelia and conidia were collected using a sterile toothpick and placed into an extraction buffer $(1 \mathrm{M}$ of $\mathrm{KCl}$, $100 \mathrm{mM}$ of Tris- $\mathrm{HCl}$, and $10 \mathrm{mM}$ of ethylenediaminetetraacetic acid [EDTA]). Genomic DNA was extracted and purified as described previously (Chi et al. 2009).

For Botrytis species identification, three different pairs of forward and reverse primers were used to amplify the $G 3 P D H, H S 60$, and $R P B 2$ regions of nuclear DNA, respectively: G3PDHfor+ $\left(5^{\prime}\right.$-ATT GACATCGTCGCTGTCAACGA) and G3PDHrev+ (5'-ACCCC ACTCGTTGTCGTACCA), HSP60for+ (5'-CAACAATTGAGATTT GCCCACAAG) and HSP60rev+ (5'-GATGGATCCAGTGGTACC GAGCAT), and RPB2for+ (5'-GATGATCGTGATCATTTCGG) and RPB2rev+ (5'-CCCATAGCTTGCTTACCCAT) (Staats et al. 2005). PCR amplifications were carried out in a $25-\mu 1$ mixture reaction containing 50 to $100 \mathrm{ng}$ of fungal DNA, $5 \mu \mathrm{l}$ of $10 \times$ Thermo Pol buffer, 2.5 $\mathrm{mM}$ of dNTPs, $10 \mathrm{pmol}$ of each primer, and $0.25 \mu \mathrm{l}$ of Taq polymerase (New England Biolabs). The PCR amplifications were accomplished using an iCycler Thermal Cycler (T100; Bio-Rad Laboratories Inc.). The following thermocycling program was used to amplify the G3PDH gene fragment: $94^{\circ} \mathrm{C}$ for $3 \mathrm{~min}$ (one cycle), denaturation at $94^{\circ} \mathrm{C}$ for $30 \mathrm{~s}$, annealing at $56^{\circ} \mathrm{C}$ for $30 \mathrm{~s}$, extension at $72^{\circ} \mathrm{C}$ for $1 \mathrm{~min}$ ( 35 cycles), and then final extension at $72^{\circ} \mathrm{C}$ for $5 \mathrm{~min}$ (one cycle). The thermocycling program used to amplify the $H S 60$ and RPB2 genes was described by Staats et al. (2005). The PCR products were visualized in red gel $(<100 \mathrm{ppm}$; Biotum) stained with $1 \%$ agarose-Trisborate-EDTA $(1 \times \mathrm{TBE})$. The PCR products were purified and sequenced in both $3^{\prime}$ and $5^{\prime}$ directions at the Arizona State University Core Laboratories. The internal transcribed spacer (ITS) regions from nonBotrytis fungal isolates were amplified using ITS1+ (5'-TCCGTAGGT GAACCTGCGG) and ITS4+ (5'-TCCTCCGCTTATTGATATGC) primers (White et al. 1990). The PCR amplifications were carried out in an iCycler Thermal Cycler (T100; Bio-Rad Laboratories Inc.) using the following thermocycling pattern: $94^{\circ} \mathrm{C}$ for $5 \mathrm{~min}$ (one cycle), denaturation at $94^{\circ} \mathrm{C}$ for $40 \mathrm{~s}$, annealing at $55^{\circ} \mathrm{C}$ for $1 \mathrm{~min}$, extension at $72^{\circ} \mathrm{C}$ for $2 \mathrm{~min}$ ( 35 cycles), and then final extension at $72^{\circ} \mathrm{C}$ for $10 \mathrm{~min}$ (one cycle). The PCR product visualization, purification, and DNA sequencing were performed as described above. Sequences were assembled and analyzed using Geneious version 11.1.3 (Biomatters Ltd.). Sequences of Botrytis and non-Botrytis fungi were entered into the National Center of Biotechnology Information Basic Local Alignment Search Tool. The accessions with higher homology were obtained from the GenBank database (https://www.ncbi.nlm.nih.gov) and used as reference for comparisons.

Fungicide resistance profiling and CCR evaluation. Commercial formulations of the following 10 active ingredients were used to determine fungicide resistance of Botrytis isolates as previously described (Dowling et al. 2016; Fernández-Ortuño et al. 2014; Hu et al., 2015, 2016): boscalid (Endura fungicide, 70\% wt/wt, FRAC 7; 
BASF Corporation), cyprodinil (Vangard WG fungicide, FRAC 9; Syngenta Crop Protection), fenhexamid (Elevate 50 WDG, FRAC 17; Arysta LifeScience), fluopyram (Luna Privilege fungicide, FRAC 7; Bayer CropScience), fludioxonil (Scholar SC fungicide, FRAC 12; Syngenta Crop Protection), iprodione (Rovral 4 Flowable, FRAC 2; Bayer CropScience), isofetamid (Kenja fungicide, 400 SC, FRAC 7; SummitAgro), penthiopyrad (Fontelis, FRAC 7; DuPont Crop Protection), pidiflumetophen (Adepidyn, FRAC 7; Syngenta), and thiophanate-methyl (Topsin M 70WP, FRAC 1; United Phosphorus Inc.). The fungicide resistance profiles were identified for all of the Botrytis isolates collected during the evaluation by testing for resistance to each of the 10 fungicides described above. The profiles were tested in 24-well plates $(15 \mathrm{~mm}$ diameter, $6 \times 4$ wells, $12.5 \times 8.5 \times 2 \mathrm{~cm}$; Thermo Fischer Scientific) using spores present in different tissues as described previously (Fernández-Ortuño et al. 2014; Hu et al. 2015, 2016). Discriminatory doses for FRAC 7 fungicides isofetamid and pidiflumetophen were chosen to be the same as was described previously for the FRAC 7 fungicide penthiopyrad $(5 \mu \mathrm{g} / \mathrm{ml})$ ( $\mathrm{Hu}$ et al. 2015). Conidia were transferred from actively growing colonies to the 24-well plates with a sterile toothpick. Mycelial growth was visually assessed after 4 days of incubation in the dark at $22^{\circ} \mathrm{C}$ as described previously (FernándezOrtuño et al. 2014)

The number of CCRs was determined for each of the 49 isolates. The isolates were classified as being simultaneously resistant to zero, one, two, three, four, five, or six chemical classes (i.e., zero to six CCR isolates). The frequency of CCR isolates was evaluated across shipments and greenhouses.

Data analysis. Data analysis was performed using JMP Pro version 13.2.0 (SAS Institute Inc., Cary, NC). Analysis of variance
(ANOVA) and the Fisher least significant difference (LSD) Student $t$ test were used to determine treatment effects and compare means between treatments at $P<0.05$, respectively.

For determination of disease incidence and severity, the data set consisted of a $2 \times 6$ factorial model consisting of two greenhouses, six shipments, and five different tissue samples per combination. When the factors were significant, the Fisher LSD Student $t$ test was used to compare means for the factor levels at $P<0.05$. Additionally, multivariate analysis was performed to determine correlations between latent infections and the evaluated tissues.

A $2 \times 6 \times 10$ unbalanced, full factorial ANOVA was performed to analyze the effect of fungicide (10), shipment (six), and greenhouse (two) factors on the fungicide resistance for all 49 Botrytis isolates collected during the evaluation period. When the factors or interactions were significant, the Fisher LSD Student $t$ test was used for comparing means for the factor levels at $P<0.05$. For CCR evaluation a full factorial ANOVA was used to determine whether the shipment, greenhouse, or the interaction of both had an effect on CCR number. When the factors or interactions were significant, the Fisher LSD Student $t$ test was used for comparing means for the factor levels at $P<0.05$.

\section{Results}

Morphological and molecular characterization of fungal isolates. The 49 single spore isolates were grouped into six morphology groups based on shape, amount of aerial mycelium, mycelium/conidia color, and distribution (Fig. 1). Morphology groups were characterized as follows: group 1: irregular, aerial, umbonate formations and strong sporulation; group 2: a homogeneous colony with copious gray sporulation; group 3: profuse, raised white

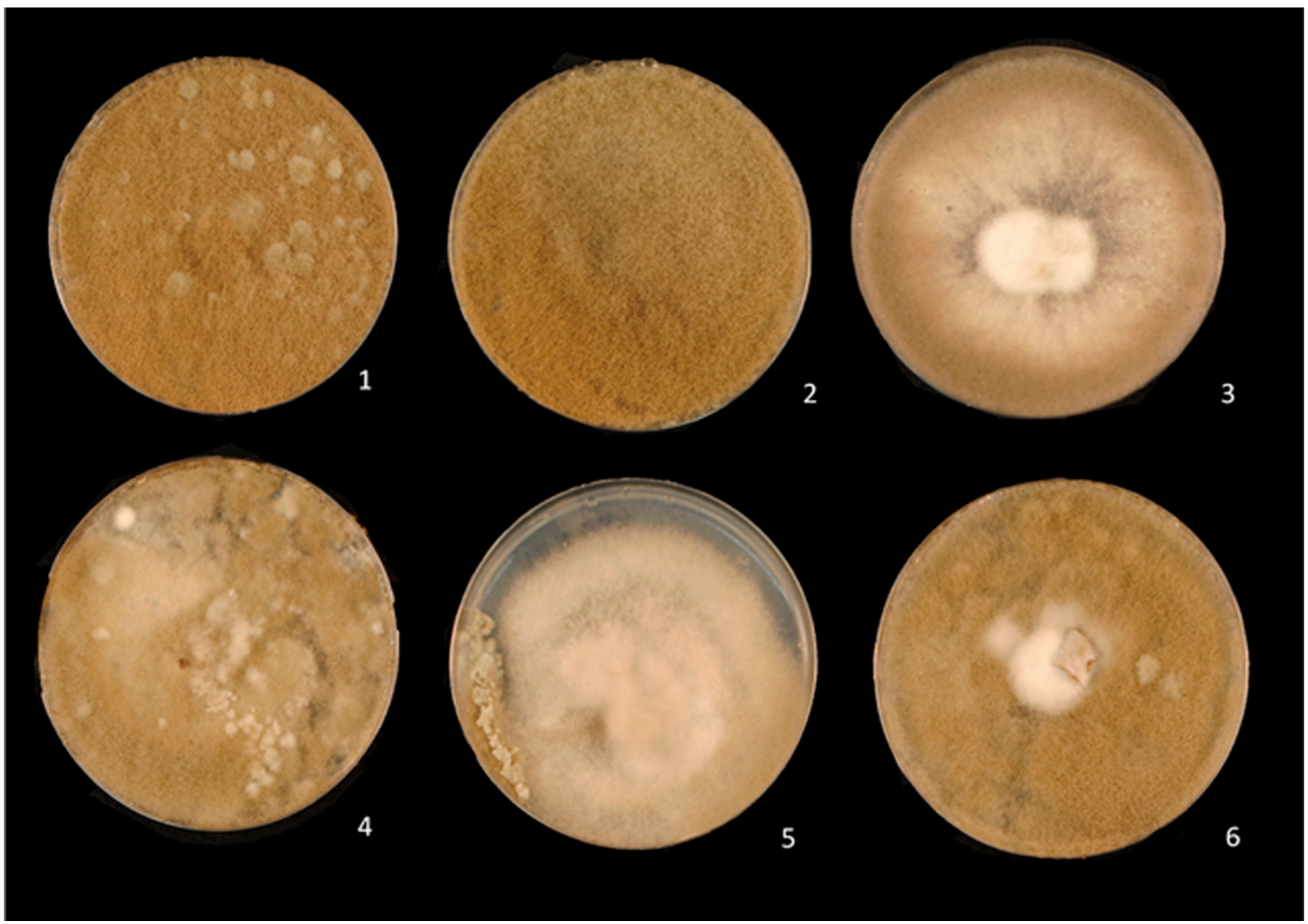

Fig. 1. Morphology groups of Botrytis cinerea cultures on potato dextrose agar. Group 1: gray, raised, sporulating mycelium with umbonate elevations nonuniformly distributed across the colony. Group 2: homogeneous raised elevation with uniform gray sporulation occurring evenly over the plate. Group 3: umbonate white mycelium without sporulation in the center of the plate. Group 4: unevenly distributed mycelium and sporulation over the plate. Elevation varies within the same colony between raised, flat and umbonate. Group 5 : predominantly white colony with little sporulation. Group 6: large areas of sporulation with umbonate elevations of white mycelium frequently at the center of the plate. 
mycelium in the center and sporulation at the edges of the colony; group 4: variable mycelium elevation and spore distribution; group 5: white mycelium with variable elevation and rare sporulation; and group 6: large sporulation evenly distributed and white umbonate mycelium at the center of the colony. Morphology group 4 was the most prevalent (20.9\%), followed by groups $6,5,3,2$, and 1 , with $20.9,14.0,14.0,14.0$, and $9.3 \%$, respectively. No differences were found in the resistance development of the different morphological groups.

Based on combined G3PDH, HS60, and RPB2 gene sequences, isolates from each morphological group were identified as $B$. cinerea Pers. sensu stricto with $100 \%$ identity. The GenBank accession numbers are listed in Table 1. Sequence length varied between 823 and $862 \mathrm{bp}, 947$ and $999 \mathrm{bp}$, and 1,086 and 1,106 bp for G3PDH, HS60, and $R P B 2$ sequences, respectively (Table 1 ).

Morphological characterization and sequence analysis of the ITS regions from non-Botrytis fungi revealed their identity as Alternaria alternata (99\% identity), Cladosporium cladosporioides $(100 \%$ identity), Epicoccum nigrum (100\% identity), Penicillium citrinum (100\% identity), Aspergillus brasiliensis (99\% identity), and Diplodia sp. (98\% identity) (GenBank accession numbers MK388046, MK388045, MK388043, MK388044, MK392507, and MK392508, respectively).

Pathogenicity on rose petals was confirmed for Alternaria alternata, E. nigrum, P. citrinum, and C. cladosporioides but not for Aspergillus brasiliensis and Diplodia sp. isolates. The incidence of Alternaria alternata, E. nigrum, P. citrinum, and C. cladosporioides in all shipments and greenhouses combined was 5.1, 2.7, 2.6, and $1.7 \%$, respectively.

Alternaria alternata symptoms in petal tissue initially appeared 4 days after inoculation as circular, necrotic lesions that rapidly turned into dark brown to black spots in the petals and showed a olive-green to black sporulating area at $22^{\circ} \mathrm{C}$ and $100 \%$ relative humidity, often with a black halo. Alternaria alternata isolates developed circular olive-green colonies after 10 days on PDA, with lighter margins and dark green to black centers. Conidia were ovate, were light brown in color, presented vertical and transversal walls, and were cylindrical to elongated in shape toward the base. Conidia length and width were on average $28.5 \mu \mathrm{m}$ and $14.4 \mu \mathrm{m}(n=30)$, respectively. Conidial chains and septate brown hyphae were also observed.

E. nigrum caused irregular to circular necrotic lesions 5 days after inoculation. Mycelia development on the tissue surface appeared approximately 7 days after inoculation. Colonies on PDA were initially (day 5 to 6) white to light pink but turned into aerial, interspersed black and white mycelia with dark conidiophores through the center of the colony after 10 days. Globose, dark brown multinucleate conidia were developed over brown mycelia, with an average radial diameter of $17.32 \mu \mathrm{m}(n=30)$.

Plant tissue infected with $P$. citrinum revealed light-brown necrotic lesions 3 days after inoculation and subsequently formed green to blue sporulating areas (day 7). Sporulating areas presented a white margin. Light to olive-green colonies developed on PDA with white and irregular edges. Colonies appeared powdery as a result of abundant conidia development. The PDA medium turned yellow. Hyaline to blue, round conidia were observed, with an average radial diameter of $2.55 \mu \mathrm{m}(n=30)$.

Symptoms and signs of $C$. cladosporioides included rounded to irregular shaped, sporulating areas over large, necrotic, discolored petal tissue. Areas of sporulation appeared powdery, olive green to light brown. Colonies on PDA were velvety, olive green with lighter-color margins usually irregularly shaped. Hyaline to brown, limoniform to elliptical conidia were observed, length and width were on average 8.01 and $3.93 \mu \mathrm{m}(n=30)$, respectively.

Botrytis incidence and severity on cut rose tissues. Evaluation of latent infections on cut flower roses showed that $B$. cinerea was the most frequently isolated pathogen. A total of $14.6 \%$ of sampled rose tissue showed symptoms and/or signs of $B$. cinerea. Greenhouse and shipment did not have an effect on $B$. cinerea incidence or severity, but $B$. cinerea incidence and severity were differentially expressed ( $P<0.005 \%$, and $P<0.01 \%$, respectively) on the different rose tissues. Incidence (Fig. 2A) in the petals (50\%) was significantly higher than in stems $(8.3 \%)$, sepal (3.3\%), stamen and ovary (3.3\%), and leaf $(0 \%)$, and no significant differences were found among the last four tissues. Disease severity (Fig. 2B) was greater in the petals $(9.5 \%)$ than in the stamen and ovary tissues $(3.0 \%)$, sepals $(1.7 \%)$, and leaves $(0 \%)$.

The interaction between greenhouse and tissue was significant $(P<0.05 \%)$ for disease incidence. Specifically, the percentage of affected petals was higher in greenhouse A $(63.3 \%)$ than greenhouse B $(36.7 \% ; P<0.05 \%)$, but no differences were found for the other rose tissues between greenhouses. No differences were observed for the main effect of shipment or greenhouse on disease incidence or severity. Multivariate analysis showed no correlation between tissues for $B$. cinerea incidence or severity (i.e., the infection of one tissue was not a prerequisite to infection of another; data not shown).

Fungicide resistance profiling. Fungicide, shipment, greenhouse, and their interactions were significant for the presence of fungicide resistance $(P<0.005)$. Across greenhouses and shipments, $B$. cinerea isolates exhibited a high occurrence of resistance to thiophanate-methyl, iprodione, boscalid, and cyprodinil, with average frequencies of $86.7,78.8,77.1$, and $75.4 \%$, respectively $(P=$ 0.05; Fig. 3). Differences in resistance to isofetamid, fluopyram, penthiopyrad, and fenhexamid were observed between greenhouses A and B. A high percentage $(66.7 \%)$ of isolates from greenhouse B was resistant to isofetamid, fluopyram, penthiopyrad, and a more moderate percentage $(47.5 \%)$ of the isolates from the same greenhouse was resistant to fenhexamid. Resistance frequencies to isofetamid, fluopyram, penthiopyrad, and fenhexamid in isolates from greenhouse A were 19.2, 22.5, 33.8, and $26.3 \%$, respectively.

The frequency of fludioxonil resistant isolates was relatively low for both greenhouses, with an average frequency of $23.3 \%$

Table 1. GenBank accession numbers of fragments generated from Botrytis isolated from roses

\begin{tabular}{|c|c|c|c|c|c|c|}
\hline \multirow[b]{3}{*}{ Isolate identification number } & \multicolumn{6}{|c|}{ Gene $^{\mathbf{a}}$} \\
\hline & \multicolumn{2}{|c|}{ G3PDH } & \multicolumn{2}{|c|}{$R P B 2$} & \multicolumn{2}{|c|}{ HS60 } \\
\hline & Accession number & Length (bp) & Accession number & Length (bp) & Accession number & Length (bp) \\
\hline S1GAR4S & MK388067 & 831 & MK388057 & 1092 & MK388047 & 999 \\
\hline S1GBR3O & MK388068 & 841 & MK388058 & 1090 & MK388048 & 947 \\
\hline S2GAR2O & MK388069 & 862 & MK388059 & 1104 & MK388049 & 984 \\
\hline S2GAR2M & MK388070 & 841 & MK388060 & 1094 & MK388050 & 999 \\
\hline S2GAR4O & MK388071 & 837 & MK388061 & 1086 & MK388051 & 983 \\
\hline S2GBR3O & MK388072 & 826 & MK388062 & 1089 & MK388052 & 974 \\
\hline S4GBR4O & MK388073 & 853 & MK388063 & 1106 & MK388053 & 980 \\
\hline S5GAR1M & MK388074 & 841 & MK388064 & 1087 & MK388054 & 975 \\
\hline S5GBR4S & MK388075 & 861 & MK388065 & 1098 & MK388055 & 968 \\
\hline S5GBR4O & MK388076 & 823 & MK388066 & 1099 & MK388056 & 968 \\
\hline
\end{tabular}

${ }^{\text {a }} G 3 P D H=$ glyceraldehyde 3-phosphate dehydrogenase, $R P B 2=$ DNA-dependent RNA polymerase subunit II, and $H S 60=$ heat-shock protein 60 . 
$(P=0.05$; Fig. 3). No resistance was found to pydiflumetophen. The percentage of isolates displaying fungicide resistance varied with shipments and ranged from $0 \%$ at shipment 2 from greenhouse A to $73 \%$ at shipments 1 and 3 from greenhouse B (Fig. 4; Supplementary Table S1). Shipments 1, 3, 4, and 5 had the highest resistance frequencies and shipments from greenhouse B had higher fungicide resistance frequencies than greenhouse $\mathrm{A}$ in four of the six shipments.

CCR evaluation. No differences were observed in numbers of isolates with multiple CCR between greenhouses; however, differences were observed among shipments $(P<0.001)$ (Supplementary Table S2). The isolates from shipment 2 revealed a smaller proportion of four, five, and six CCR isolates compared with other shipments. A one-direction ANOVA was performed to evaluate whether resistance profiles were related to morphological group, shipment, or greenhouse. No effect of morphological type or greenhouse was determined for the resistance profile response; however, shipment had an effect on the resistance and CCR $(P<0.001)$. Shipments 3 and 4 had a higher proportion of isolates with simultaneous resistance to FRAC 1, 2, 7, 9, and 17 fungicides and FRAC 1, 2, 7, 9, 12 , and 17 fungicides, respectively.

\section{Discussion}

This study showed that gray mold was the most common disease in cut roses from Colombia. This is consistent with previous studies that showed B. cinerea to be the most frequent and limiting pathogen for production and postharvest management of cut rose flowers (Pie and De Leeuw 1991). We also confirmed PCR-RFLP results obtained by Gómez-Rodríguez (2013) showing that the gray mold pathogen of roses is $B$. cinerea Pers. sensu stricto. Other pathogens affecting postharvest quality of cut roses from Colombia were found in lower frequencies. Alternaria alternata was the second most frequently isolated pathogen, which has been described as one of the main rose pathogens in Bangladesh (Ghosh and Shamsi 2014), Pakistan (Abbas et al. 2017), and Ecuador (León and Herrera 2016), as well as in other
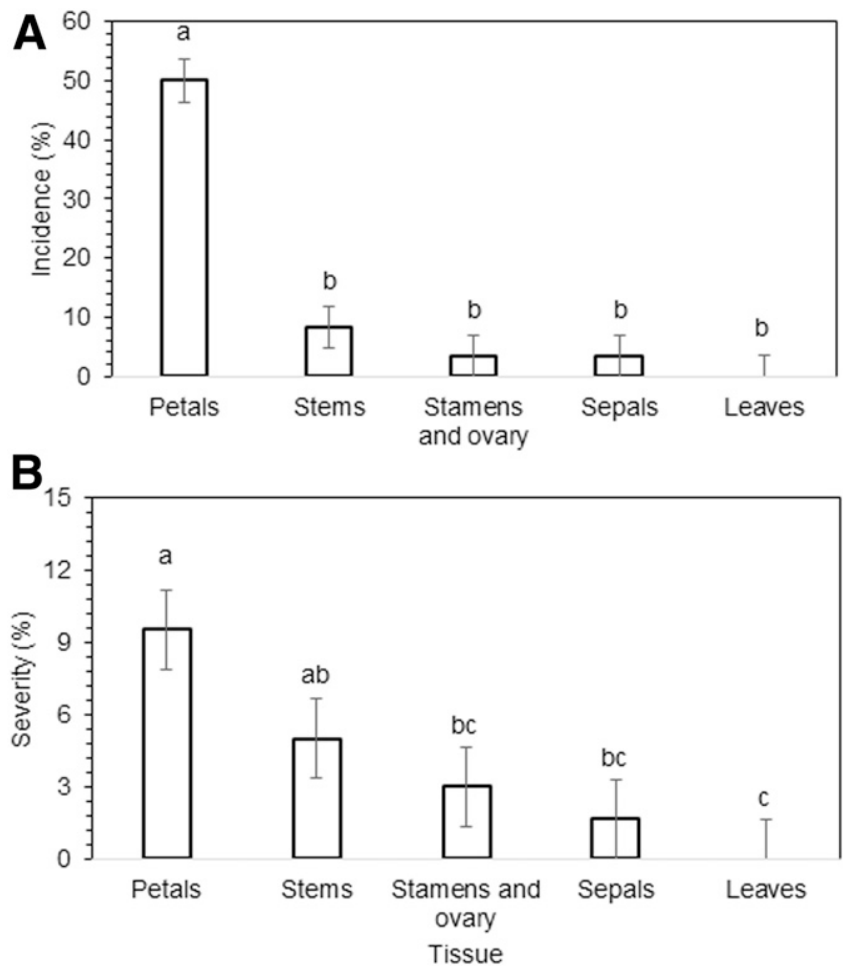

Fig. 2. A, Botrytis cinerea incidence determined as the percentage of tissue with any symptoms or signs and $\mathbf{B}$, severity determined as the percentage of symptomatic area for each rose tissue from six shipments and two greenhouses. The least significant difference test $(\alpha=0.05)$ was used. Error bars represent +1 SE. Different letters indicate significantly different responses within tissues. flower crops such as sunflowers (Kgatle et al. 2018). However, to our knowledge, this research is the first report of Alternaria alternata as a pathogen of roses from Colombia. C. cladosporioides, Epicoccum sp., Penicillium sp., Aspergillus sp., and Diplodia sp. have also been described as pathogens for roses and other ornamental plants (Bensch et al. 2010; Ghosh and Shamsi 2014; Yong 2004), but this is the first report of $E$. nigrum and $P$. citrinum as rose pathogens.

Some studies have examined levels of susceptibility of rose cultivars to B. cinerea (Friedman et al. 2010; Hammer and Evensen 1991) and differences in susceptibility among rose cultivars were found. Differences in susceptibility have been attributed to the thickness of petal cuticles (Hammer and Evensen 1991), genetic background, polyphenolic compound levels (Lattanzio et al. 2006; Nagpala et al. 2016), and pectin levels in the cell walls (Lionetti et al. 2007). The cultivar used in this study, Orange Crush, is a particularly susceptible cultivar according to the producers in Colombia. The petals of Orange Crush roses yielded more $B$. cinerea infections than any other tissue. On grapes and strawberries, flower petals have been characterized not only as the most susceptible tissue for Botrytis infection but also as the site of primary infections (Williamson et al. 2007). Host tissue susceptibility to Botrytis infection has been related to different factors such as tissue maturity (Droby and Lichter 2007),

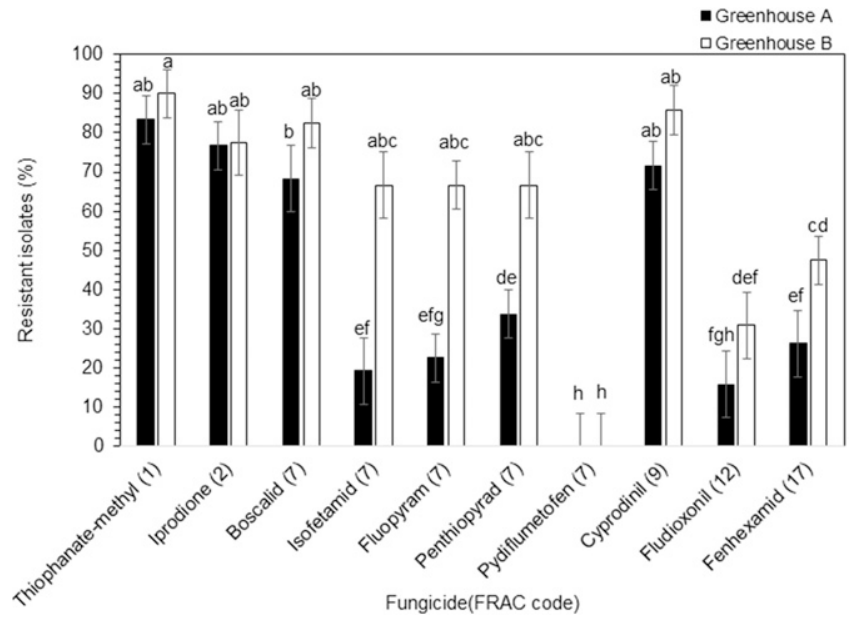

Fig. 3. Percentage of fungicide resistant isolates recorded from six shipments from both greenhouse A $(n=30)$ and greenhouse $\mathrm{B}(n=19)$ averaged over six shipments. The least significant difference test $(\alpha=0.05)$ was used. Error bars represent $+1 \mathrm{SE}$. Different letters indicate significantly different responses within shipments and greenhouses.

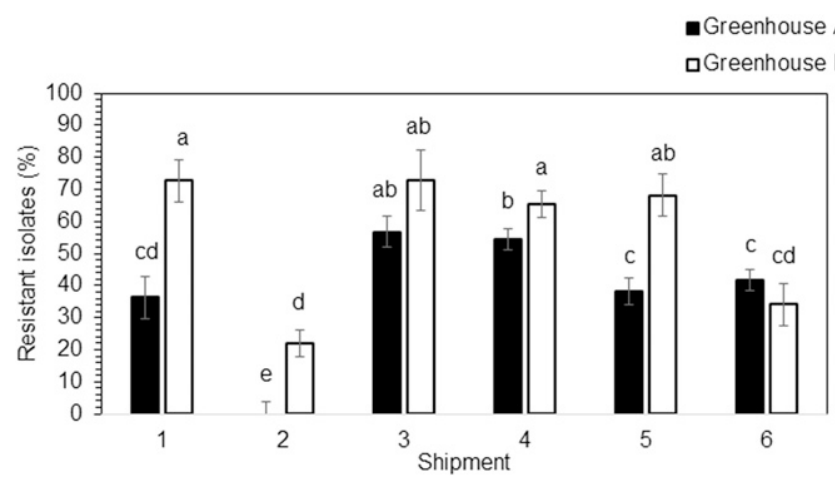

Fig. 4. Botrytis cinerea isolates resistant to fungicides from infected rose tissues from both greenhouse $\mathrm{A}(n=30)$ and greenhouse $\mathrm{B}(n=19)$ averaged over six shipments. Least squares means were calculated based on a least significant difference test $(\alpha=$ $0.05)$. Error bars represent $+1 \mathrm{SE}$. Different letters indicate significantly different responses within fungicides and greenhouses. 
plant hormones, free radical levels (Elad 1997), phenolic compounds (Kretschmer et al. 2007), and plant nutrition (Elad 1988; Lattanzio et al. 2006; Volpin 1991). It is possible that the differential response of $B$. cinerea incidence in the evaluated rose tissues may be related to some of these compounds; however, further investigation needs to be done to determine the cause of the variations on the Botrytis incidence in the different rose tissues.

The cut roses were asymptomatic upon delivery to our research facility but developed disease on various tissues after incubation. This coincides with the two stages described for Botrytis infection on cut roses (Elad 1988). In the first stage, often referred to as latent infection, conidia germinate on rose tissue followed by limited colonization that is macroscopically invisible. In the second stage, mycelia continue to expand in the rose tissue under favorable environmental conditions (e.g., relative humidity $>94 \%$ ). Visible necrotic areas appear as the disease advances to finally develop mycelia that will produce new conidia. This second stage of gray mold development during shipment was likely suppressed by forced air cooling of the bouquets in shipping boxes soon after harvest and by keeping the boxes at $4^{\circ} \mathrm{C}$ during shipping.

Fungicide resistance in $B$. cinerea from agricultural crops is common and was also confirmed in isolates from cut roses in this study. Fungicide resistance in B. cinerea isolates has been reported for different crops, including strawberries, grapes, apples, and some vegetables (Grabke et al. 2012; Leroch et al. 2013; Weber 2011). In this study, $B$. cinerea isolates from cut roses of both greenhouses were frequently resistant to thiophanate-methyl (FRAC 1), iprodione (FRAC 2), cyprodinil (FRAC 9), and boscalid (FRAC 7). Thiophanate-methyl or any other FRAC 1 had not been used by the Colombian rose producer in more than a decade because of resistance concerns. This underscores the stability of resistance to FRAC 1 fungicides in $B$. cinerea and confirms observations of other studies (Ma and Michailides 2005; Malandrakis et al. 2011). FRAC 2 fungicides had not been used for several years according to the producer but resistance still persisted in a large proportion of the population. This persistence of resistance to FRAC 2 contradicts other studies showing that once applications of FRAC 2 fungicides are interrupted for a long period of time, the susceptible population will recover, making the fungicide efficient again (Elad et al. 1992; Leroux et al. 2002). It is possible that the routine applications of FRAC 12 fungicide fludioxonil maintained resistance to FRAC 2 fungicides in the population. Depending on the molecular basis of resistance, some genotypes do reveal positive cross-resistance between fludioxonil (FRAC 12) and iprodione (FRAC 2), as documented for Alternaria alternata from tomatoes (Malandrakis et al. 2015). FRAC 9 fungicides had still routinely been used in both greenhouses up to the onset of this study either as solo products or in a mixture with fludioxonil, which may explain the high frequency of resistance in both greenhouses.

FRAC 7 boscalid was one of the first FRAC 7 fungicides introduced for gray mold control and had been used extensively in the operation in previous years. Resistance to this particular chemical is conferred by many point mutations in the succinate dehydrogenase B subunits (Amiri et al. 2013; Hu et al. 2015). Many of these genotypes can also be selected by carboxin, another succinate dehydrogenase inhibitor (SDHI) fungicide (Avenot and Michailides 2010). A review of the spray history revealed that carboxin and fluxapyroxad had been used in the 7 weeks prior to the first shipment in both greenhouses, and thus the populations were exposed to roughly the same selection pressure. That may explain the consistent and high frequency of resistance across both greenhouses.

Resistance to newer-generation FRAC 7 fungicides, including isofetamid, fluopyram, and penthiopyrad, was identified but none of these had ever been used at the farm. Furthermore, resistance frequencies were significantly different between greenhouses. This can be explained by incomplete cross-resistance among FRAC 7 fungicides, where certain point mutations in SDHI subunit B confer resistance to specific SDHIs (Hu et al. 2016). It is also possible that the pathogen populations in the two greenhouses were subject to different genetic influx from several sources such as from weeds, nearby greenhouses, or compost piles. Resistance frequencies were fewer in isolates from shipments 2 and 6 , which coincided with a reduced number of site-specific fungicides applied prior to these shipments. According to the producer, the numbers of single-site fungicide applications made in the 4 weeks previous to each shipment were five, one, five, eight, five, and two (in form of rotations of FRAC codes 3 , $7,9,11$, and 29) from shipments 1 to 6 , respectively. This would support the hypothesis that the selection of resistant genotypes is directly linked to the number of applications of selective fungicides. The differences in resistance frequencies among FRAC 7 fungicides are a function of genotype selection and differences in intrinsic activity. Pydiflumetofen has the highest intrinsic activity among the FRAC 7 fungicides tested and can inhibit mycelium of $B$. cinerea that at the same discriminatory dose $(5 \mu \mathrm{g} / \mathrm{ml}$ active ingredient $)$ can overcome exposure to penthiopyrad, fluopyram, and isofetamid.

Farm managers in Colombia have been rotating fungicides to avoid or delay resistance development for years. However, the number of effective and available fungicides is limited to four to five single-site fungicides, which results in producers using these FRAC codes multiple times per year. In this study, isolates with resistance to fungicides of multiple FRAC codes were found, which is consistent with observations in other crops (Amiri et al. 2013; Chen et al. 2016; Leroch et al. 2013). For example, isolates of $B$. cinerea collected from strawberries in Europe and the United States revealed resistance to five and more chemical classes of fungicides (Fernández-Ortuño et al. 2014; Leroch et al. 2013). Research shows that the development of resistance to multiple chemical classes is a consequence of stepwise accumulation of resistance to fungicides often based on target gene modifications rather than a single mechanism of resistance such as ATP-binding cassette transporter activity (Li et al. 2012; Nakajima et al. 2001). Rotation of fungicides may therefore continue to select for such phenotypes and not lead to effective disease management (Hu et al. 2016).

Continual production of roses occurs throughout the year in humid greenhouses that provide optimal conditions for gray mold development. Under these conditions, it is difficult to implement resistance management strategies without having to use fungicides frequently. In the absence of gray mold-resistant rose cultivars, only an integrated approach including cultural practices, the integration of multisite and single-site fungicides, extended spray intervals, and perhaps integration of biological control options for gray mold management will result in sustainable disease management.

\section{Acknowledgments}

We thank Dr. William Bridges for support with the statistical analysis and Patricia Karen Bryson and Kelly Lewis for technical support.

\section{Literature Cited}

Abbas, M. F., Khan, A.-U.-D., Rafique, K., Qadir, A., Rashid, A., Qamar, M. I., Rafique, M., and Gleason, M. 2017. First report of Alternaria black spot of rose caused by Alternaria alternata in Pakistan. Plant Dis. 101:1676.

Amiri, A., Heath, S. M., and Peres, N. A. 2013. Resistance to fluopyram, fluxapyroxad, and penthiopyrad in Botrytis cinerea from strawberry. Plant Dis. 98:532-539

Andrew, M., Barua, R., Short, S. M., and Kohn, L. M. 2012. Evidence for a common toolbox based on necrotrophy in a fungal lineage spanning necrotrophs, biotrophs, endophytes, host generalists and specialists. PLoS One 7:e29943.

Avenot, H. F., and Michailides, T. J. 2010. Progress in understanding molecular mechanisms and evolution of resistance to succinate dehydrogenase inhibiting (SDHI) fungicides in phytopathogenic fungi. Crop Prot. 29:643-651.

Bensch, K., Groenewald, J. Z., Dijksterhuis, J., Starink-Willemse, M., Andersen, B., Summerell, B. A., Shin, H.-D., Dugan, F. M., Schroers, H.-D., Braun, U., and Crous, P. W. 2010. Species and ecological diversity within the Cladosporium cladosporioides complex (Davidiellaceae, Capnodiales). Stud. Mycol. 67:1-94.

Chen, S. N., Luo, C. X., Hu, M. J., and Schnabel, G. 2016. Fitness and competitive ability of Botrytis cinerea isolates with resistance to multiple chemical classes of fungicides. Phytopathology 106:997-1005.

Chi, M.-H., Park, S.-Y., and Lee, Y.-H. 2009. A quick and safe method for fungal DNA extraction. Plant Pathol. J. 25:108-111.

Dowling, M. E., Hu, M.-J., Schmitz, L. T., Wilson, J. R., and Schnabel, G. 2016 Characterization of Botrytis cinerea isolates from strawberry with reduced sensitivity to polyoxin D zinc salt. Plant Dis. 100:2057-2061. 
Dowling, M. E., and Schnabel, G. 2017. First report of Botrytis mali causing gray mold on strawberry in the United States. Plant Dis. 101:1034.

Droby, S., and Lichter, A. 2007. Post-harvest Botrytis infection: Etiology, development and management. Pages 349-367 in: Botrytis: Biology, Pathology and Control. Y. Elad, B. Williamson, P. Tudzynski, and N. Delen, eds. Springer, Dordrecht, The Netherlands.

Elad, Y. 1988. Latent infection of Botrytis cinerea in rose flowers and combined chemical and physiological control of the disease. Crop Prot. 7:361-366.

Elad, Y. 1997. Responses of plants to infection by Botrytis cinerea and novel means involved in reducing their susceptibility to infection. Biol. Rev. 72:381-422.

Elad, Y., Williamson, B., Tudzynski, P., and Delen, N. 2007. Botrytis spp. and diseases they cause in agricultural systems - an introduction. Pages 1-8 in: Botrytis: Biology, Pathology and Control. Y. Elad, B. Williamson, P. Tudzynski, and N. Delen, eds. Springer, Dordrecht, The Netherlands.

Elad, Y., Yunis, H., and Katan, T. 1992. Multiple fungicide resistance to benzimidazoles, dicarboximides and diethofencarb in field isolates of Botrytis cinerea in Israel. Plant Pathol. 41:41-46.

Fernández-Ortuño, D., Grabke, A., Bryson, P. K., Amiri, A., Peres, N. A., and Schnabel, G. 2014. Fungicide resistance profiles in Botrytis cinerea from strawberry fields of seven southern U.S. states. Plant Dis. 98:825-833.

Fournier, E., and Giraud, T. 2008. Sympatric genetic differentiation of a generalist pathogenic fungus, Botrytis cinerea, on two different host plants, grapevine and bramble. J. Evol. Biol. 21:122-132.

Friedman, H., Agami, O., Vinokur, Y., Droby, S., Cohen, L., Refaeli, G., Resnick, N., and Umiel, N. 2010. Characterization of yield, sensitivity to Botrytis cinerea and antioxidant content of several rose species suitable for edible flowers. Sci. Hortic. -. SCI HORT-Amst. 123:395-401.

Ghosh, A., and Shamsi, S. 2014. Fungal diseases of rose plant in Bangladesh. J. Bangladesh Acad. Sci. 38:225-233.

Giraud, T., Fortini, D., Levis, C., Lamarque, C., Leroux, P., LoBuglio, K., and Brugoo, Y. 1999. Two sibling species of the Botrytis cinerea complex, transposa and vacuma, are found in sympatry on numerous host plants. Phytopathology 89:967-973.

Gómez-Rodríguez, T. 2013. Caracterizacion de aislamientos de Botrytis cinerea de rosa de la sabana de Bogota. Repositorio institucional UN. http://www.bdigital. unal.edu.co/44422/

Grabke, A., Fernández-Ortuño, D., and Schnabel, G. 2012. Fenhexamid resistance in Botrytis cinerea from strawberry fields in the Carolinas is associated with four target gene mutations. Plant Dis. 97:271-276.

Hahn, M., Viaud, M., and van Kan, J. A. L. 2014. The genome of Botrytis cinerea, a ubiquitous broad host range necrotroph. Pages 19-44 in: Genomics of PlantAssociated Fungi and Oomycetes: Dicot Pathogens.Springer Verlag, Berlin, Germany.

Hammer, P. E., and Evensen, K. B. 1991. Differences between rose cultivars in susceptibility to infection by Botrytis cinerea. Phytopathology 26:785-785

Holz, G., Coertze, S., and Williamson, B. 2007. The ecology of Botrytis on plant surfaces. Pages 9-27 in: Botrytis: Biology, Pathology and Control. Springer, Dordrecht, The Netherlands.

Hu, M.-J., Cox, K. D., and Schnabel, G. 2016. Resistance to increasing chemical classes of fungicides by virtue of "selection by association" in Botrytis cinerea. Phytopathology 106:1513-1520.

Hu, M.-J., Fernández-Ortuño, D., and Schnabel, G. 2015. Monitoring resistance to SDHI fungicides in Botrytis cinerea from strawberry fields. Plant Dis. 100: 959-965.

Jiang, J., Ding, L., Michailides, T. J., Li, H., and Ma, Z. 2009. Molecular characterization of field azoxystrobin-resistant isolates of Botrytis cinerea. Pestic. Biochem. Physiol. 93:72-76.

Kgatle, M. G., Truter, M., Ramusi, T. M., Flett, B., and Aveling, T. A. S. 2018. Alternaria alternata, the causal agent of leaf blight of sunflower in South Africa. Eur. J. Plant Pathol. 151:677-688.

Kretschmer, M., Kassemeyer, H.-H., and Hahn, M. 2007. Age-dependent grey mould susceptibility and tissue-specific defence gene activation of grapevine berry skins after infection by Botrytis cinerea. J. Phytopathol. 155:258-263.

Lattanzio, V., Lattanzio, V. M. T., and Cardinali, A. 2006. Role of phenolics in the resistance mechanisms of plants against fungal pathogens and insects. Phytochemistry 661:23-67.

León, H., and Herrera, F. A. 2016. Aislamiento, caracterización molecular y análisis de patogenicidad de Alternaria spp. sobre botones de rosa (rosa sp) y plantas de brócoli (Brassica oleracea var. Italica). http://repositorio.usfq.edu. ec/handle/23000/6158

Leroch, M., Plesken, C., Weber, R. W. S., Kauff, F., Scalliet, G., and Hahn, M 2013. Gray mold populations in german strawberry fields are resistant to multiple fungicides and dominated by a novel clade closely related to Botrytis cinerea. Appl. Environ. Microbiol. 79:159-167.

Leroux, P., Fritz, R., Debieu, D., Albertini, C., Lanen, C., Bach, J., Gredt, M., and Chapeland, F. 2002. Mechanisms of resistance to fungicides in field strains of Botrytis cinerea. Pest Manag. Sci. 58:876-888.

Li, X., Kerrigan, J., Chai, W., and Schnabel, G. 2012. Botrytis caroliniana, a new species isolated from blackberry in South Carolina. Mycologia 104: 650-658

Lionetti, V., Raiola, A., Camardella, L., Giovane, A., Obel, N., Pauly, M., Favaron, F., Cervone, F., and Bellincampi, D. 2007. Overexpression of pectin methylesterase inhibitors in Arabidopsis restricts fungal infection by Botrytis cinerea. Plant Physiol. 143:1871-1880.

Ma, Z., and Michailides, T. J. 2005. Advances in understanding molecular mechanisms of fungicide resistance and molecular detection of resistant genotypes in phytopathogenic fungi. Crop Prot. 24:853-863.

Malandrakis, A., Markoglou, A., and Ziogas, B. 2011. Molecular characterization of benzimidazole-resistant B. cinerea field isolates with reduced or enhanced sensitivity to zoxamide and diethofencarb. Pestic. Biochem. Physiol. 99: 118-124.

Malandrakis, A. A., Apostolidou, Z. A., Markoglou, A., and Flouri, F. 2015 Fitness and cross- resistance of Alternaria alternata field isolates with specific or multiple resistance to single site inhibitors and mancozeb. Eur. J. Plant Pathol. 142:489-499.

Nagpala, E. G., Guidarelli, M., Gasperotti, M., Masuero, D., Bertolini, P. Vrhovsek, U., and Baraldi, E. 2016. Polyphenols variation in fruits of the susceptible strawberry cultivar alba during ripening and upon fungal pathogen interaction and possible involvement in unripe fruit tolerance. J. Agric. Food Chem. 64:1869-1878.

Nakajima, M., Suzuki, J., Hosaka, T., Hibi, T., and Akuts, U. K. 2001. Functional analysis of an ATP-binding cassette transporter gene in Botrytis cinerea by gene disruption. J. Gen. Plant Pathol. 67:212-214.

Pie, K., and De Leeuw, G. T. N. 1991. Histopathology of the initial stages of the interaction between rose flowers and Botrytis cinerea. Neth. J. Plant Pathol. 97 335-344.

Plesken, C., Weber, R. W. S., Rupp, S., Leroch, M., and Hahn, M. 2015. Botrytis pseudocinerea is a significant pathogen of several crop plants but susceptible to displacement by fungicide-resistant $B$. cinerea strains. Appl. Environ. Microbiol. 81:7048-7056.

Rupp, S., Weber, R. W. S., Rieger, D., Detzel, P., and Hahn, M. 2017. Spread of Botrytis cinerea strains with multiple fungicide resistance in german horticulture. Front. Microbiol. 7:2075

Staats, M., van Baarlen, P., and van Kan, J. A. L. 2005. Molecular phylogeny of the plant pathogenic genus Botrytis and the evolution of host specificity. Mol. Biol. Evol. 22:333-346.

Váczy, K. Z., Sándor, E., Karaffa, L., Fekete, E., Fekete, E., Arnyasi, M., Czegledi, L., Kovics, G. J., Druzhinia, J. S., and Kubicek, C. P. 2008. Sexual recombination in the Botrytis cinerea populations in Hungarian vineyards. Phytopathology 98:1312-1319.

Volpin, H. 1991. Influence of calcium nutrition on susceptibility of rose flowers to Botrytis blight. Phytopathology 81:1390.

Vrind, T. A. 2005. The Botrytis problem in figures. Acta Hortic. 669:99-102.

Walker, A. S. 2016. Diversity within and between species of Botrytis. Pages 91-125 in: Botrytis - The Fungus, the Pathogen and Its Management in Agricultural Systems. Fillinger, S., and Elad, Y., eds. Springer International Publishing, Cham, Switzerland.

Weber, R. W. S. 2011. Resistance of Botrytis cinerea to multiple fungicides in northern German small-fruit production. Plant Dis. 95:1263-1269.

White, T. J., Bruns, T., Lee, S., and Taylor, J. 1990. Amplification and direct sequencing of fungal ribosomal RNA genes for phylogenetics. Pages 315-322 in: PCR Protocols: A Guide to Methods and Applications. Academic Press, San Diego, CA

Williamson, B., Tudzynski, B., Tudzynski, P., and van Kan, J. A. L. 2007. Botrytis cinerea: The cause of grey mould disease. Mol. Plant Pathol. 8:561-580.

Yong, A. 2004. El cultivo del rosal y su propagación. Cult. Trop. 25:53-57. 